\title{
The Effect of Use the Camtasia Studio 8 Learning Media on Student Learning Outcomes in Class VII Middle School Swasta Jambi Medan
}

\author{
Hernawaty $^{1} \quad$ Normina Purba $^{1} \quad$ Nelson Tarigan ${ }^{2}$ \\ 1.Indonesian Language and Literature Education STKIP Riama Medan, Indonesia \\ 2.Civic Education STKIP Riama Medan, Indonesia
}

\begin{abstract}
The purpose of this paper is to determine the effect of using Camtasia Studio 8 learning media on student learning outcomes. This paper uses the experimental method, the experimental design used is a non-equivalent control group design which is a form of quasi experimental research method. This study was divided into two groups, the experimental group was research using Camtasia Studio 8 learning media, and the control group without using learning media. The population in this study were all students of class VII Medan Jambi Private Middle School as many as 93 people, while the sample in this study were 61 people, one class as an experimental class and one class as a control class. From the results of research and data analysis it can be concluded that there is a very significant effect using Camtasia Studio 8 learning media on student learning outcomes in class VII Jambi Jambi Private Middle School, where student learning outcomes using Camtasia Studio 8 learning media are higher than learning outcomes without using learning media. The results obtained by using the Camtasia Studio 8 learning media are 87.73, while the results obtained without using Camtasia Studio 8 learning media are 58.80. So, it can be concluded that using Camtasia Studio 8 learning media in class VII of Jambi Medan Private Middle School is more effective in improving student learning outcomes.
\end{abstract}

Keywords: Camtasia Studio 8 learning media, learning outcomes, and Junior high school Private Jambi Medan DOI: $10.7176 / \mathrm{JEP} / 10-18-03$

Publication date:June $30^{\text {th }} 2019$

\section{Introduction}

The use of media in the learning process can contribute optimally to the quality of learning outcomes, so the use of learning media must be integrated with student learning activities. The use of instructional media is very effective in the process of delivering information and understanding of educational material to all students in the school. Computer-based multimedia is one of the media that combines text, graphics, animated sounds and video.

Educational science is a science that requires facts or reality in fact, to present a learning material requires objective data. That is, students must really be able to see clearly and understand the material taught so as to achieve specific learning goals from the material. Camtasia Studio 8 learning media can provide an interesting learning experience so that it can be stored long in the memory of students.

In achieving a success the learning process is greatly influenced by the teacher in the learning process. Teachers as the main component in the world of education must be able to design interesting learning processes. One of the requirements of the teacher in improving the quality of student learning outcomes is by choosing and using learning media that are appropriate to the teaching material that will be given to students, taking into account the ability of the learning media, arousing sensory stimulation of vision, hearing and smell or its suitability to the level learning hierarchy. Comparison of the acquisition of learning outcomes through the sense of sight and hearing is very prominent. Approximately $90 \%$ of one's learning outcomes are obtained through the senses of view and only about $5 \%$ is obtained through the senses of hearing, while the other 5\% are with other senses (Bough in Arsyad, 2009).

The junior high schools Private Jambi Medan is one of the junior high schools that has learning facilities in the form of multimedia LCD (Liquid Crystal Display) which is connected to a computer (laptop) then projected onto the screen. But unfortunately the use of learning media such as camtasia studio 8 has never been used in the learning process activities, this is due to the lack of teacher creativity in designing innovative learning media. There are still teachers who use media such as charta, even though almost all the teachers at the Medan Jambi Private Middle School already have personal laptops. But in fact the learning process that has been running so far is still conventional, namely a teacher-centered learning system. The teacher is the only source of information for students besides their learning books, so communication is only one-way. The expected condition with the presence of multimedia-based learning media such as Camtasia Studio 8 can be used as a variation in the learning process so that it can attract students' interest in learning and the course of interesting learning is ultimately expected to improve learning outcomes at Jambi Private Middle School. There are still many students who get grades 55-65. The value of these students has not yet reached the KKM value set at school, namely 70 by using the 2013 curriculum (K-13). In addition, students' motivation and learning interests are also low, this 
can be seen by their lack of passion or interest in learning.

Multimedia based learning media such as Camtasia Studio 8 can stimulate students 'enthusiasm and learning motivation because of the colorful elements of sound and images that attract students' attention to learning. Students will learn more than if the subject matter is presented only with a stimulus view or only a listening stimulus. Students will also be more challenged to explore the lesson by finding problems from the subject matter presented through the Camtasia Studio 8 learning media that is displayed. In addition, by seeing and hearing students will more easily absorb and remember the subject matter presented.

The latest solution is the use of Camtasia Studio 8 learning media which is a more advanced form of learning video. In using Camtasia Studio 8 learning media learning becomes more interactive. Where students can also answer questions that appear at the beginning, in the middle, or at the end of the presentation of the learning video. In other words, the use of multimedia such as the Camtasia Studio 8 learning media can improve student learning outcomes and can be an alternative problem solving above.

The use of multimedia-based learning media such as Camtasia Studio 8 learning media is considered more effective in student learning success. The effectiveness of using audio visual media has been proven to improve student learning outcomes. As stated by Ginting (2006), that student learning outcomes using audio visual media are more effective than student learning outcomes without using audio visual. Likewise the results of other studies, show that the learning outcomes of students who use IMMI (Interactive Multi Media Instruction) are higher than the learning outcomes of students who are taught without using IMMI. Students from the experimental class have a posttest average value of 60.05 , while the control class students have a posttest average of 50.06. Thus there is a significant difference between the two that is equal to $9 \%$.

\section{Research Methods}

\section{Population and Samples}

The population in this study were all VII grade students in the junior high school private Jambi Medan consisting of three classes namely VII-1 (31 students), VII-2 (30 students), and VII-3 (32 students), with the number a total of 93 students will be chosen randomly to be used as samples in this study.

Table 2.1. The total number of class VII students at Medan Jambi Private Middle School

\begin{tabular}{|c|c|c|}
\hline No. & Class & Total \\
\hline 1 & VII-1 & 31 \\
\hline 2 & VII-2 & 30 \\
\hline 3 & VII-3 & 32 \\
\hline & Total & 93 \\
\hline
\end{tabular}

\section{Sample}

This sampling is done by using a random sampling method that is taking 2 class units from 3 existing classes. Of the 2 classes the class is drawn which will be used as the experimental class and the control class. After conducting random sampling, the VII-1 class was chosen as the experimental class and VII-2 class as the control class with 61 students. The method used in this study is an experimental method with a post-test only design two-group design. This method is used because the author describes the learning outcomes of students using Camtasia Studio 8 media and without using learning media.

The design of this study was two-group post test only design. The design of this study aims to show differences in achievement between the experimental group and the achievement of the control group. Based on Arikunto (2013), in making a research design with two-group post test only design can be seen in Table 2.2 below.

Table 2.2. Experimental Design Two-Group Post Test Only Design
\begin{tabular}{|c|c|c|}
\hline Class & Variable & Post Test \\
\hline Eksperimen & $\mathbf{X}$ & T \\
\hline Kontrol & Y & T \\
\hline
\end{tabular}

Information:

$\mathrm{X}$ : Using media Camtasia Studio 8

Y : Without using media Camtasia Studio 8

$\mathrm{T}$ : Test student learning outcomes

\section{Results and Discussion}

\section{Description of Research Data}

To get data in a study, first distribute questionnaires to the respondents. Then an instrument trial was conducted on the influence of Camtasia Studio 8 learning media at junior high school Private Jambi Medan, then tested the 
validity. From the results of the tests conducted there were 30 questions where valid 25 questions and 5 questions were invalid. The valid question is then used as a data collection tool by comparing $r$ count with $r$ table for $\mathrm{N}=30$ at the significance level $\alpha=0.05$ obtained rtable $=0.361$. So that 25 valid items are used to capture questionnaires about learning outcomes.

This research is an experimental research that uses two variables, namely the experimental class and the control class. In the experimental class Camtasia Studio 8 learning media was used in students of class VII-1 Jambi Private Junior High School Medan, while in the control class Camtasia Studio 8 was used without learning media on the learning outcomes of students of class VII-2 Jambi Private Junior High School Medan.

\section{Description of Experimental Class Data}

Based on the value of student learning outcomes using Camtasia Studio 8 learning media at the pretest obtained an average value of 54.67, the spread of values between 45 and 60 . The lowest value is 45 while the highest value is 60.96 the lowest is 76 , while the highest value is 96 . Then the mean value of learning outcomes using Camtasia Studio 8 learning media is 87.73 .

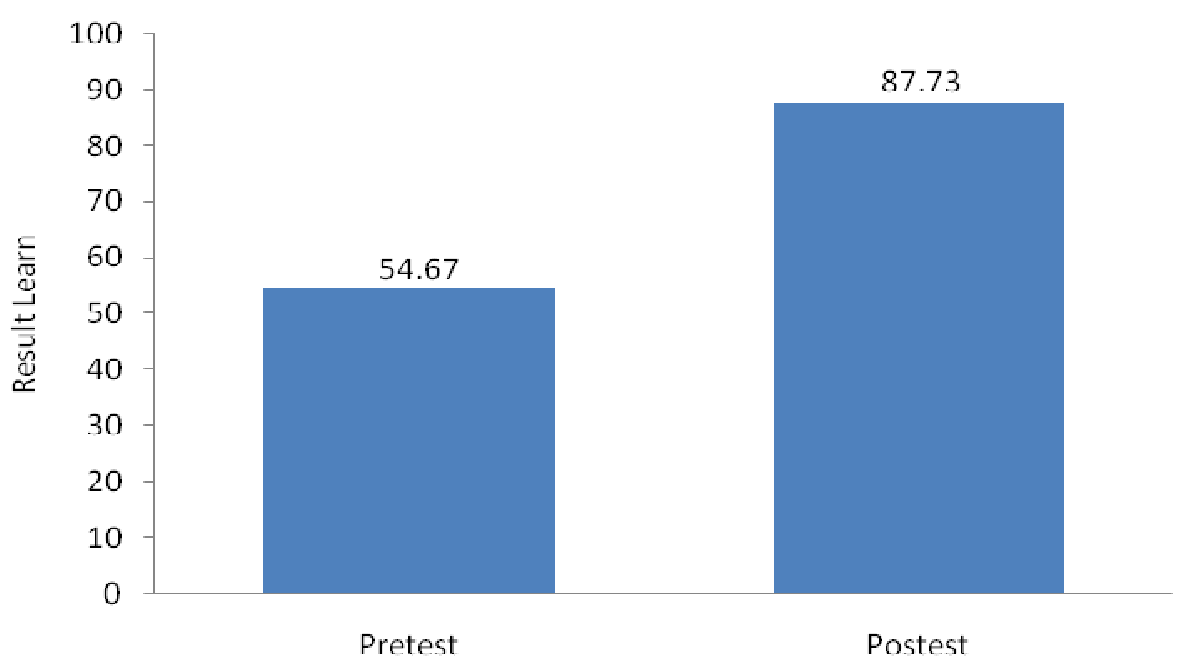

Fig. 3.1. Frequency of Experimental Class Values

\section{Description of Data Class Control}

Based on the value of student learning outcomes without using Camtasia Studio 8 learning media above, the value of the pretest is spread between 45 to 60 . The lowest value is 45 , while the highest value is 60 . It can be seen the average value of learning without using Camtasia Studio 8 is 52.50. In the posttest the spread of values is between 48 and 64 . The lowest value is 48 , while the highest value is 64 . It can be seen that the average value of learning outcomes without using Camtasia Studio 8 learning media is 58.80.

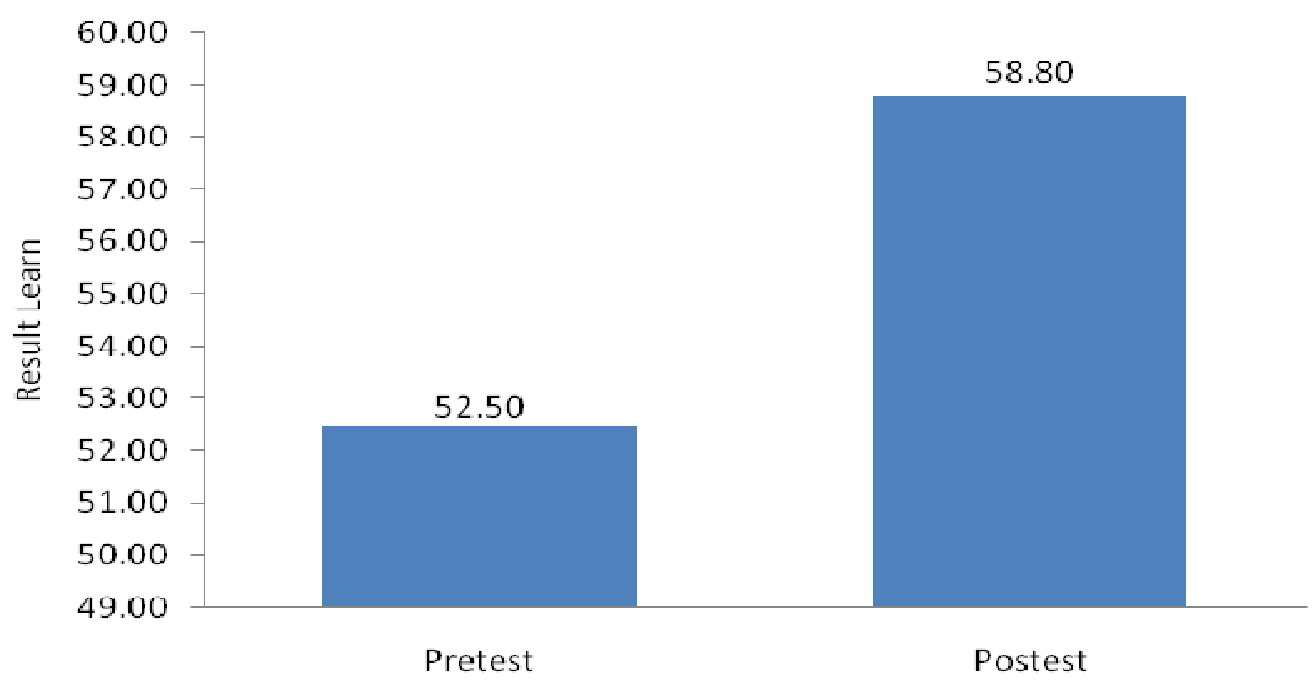

Fig. 3.2. Frequency of Control Class Values 


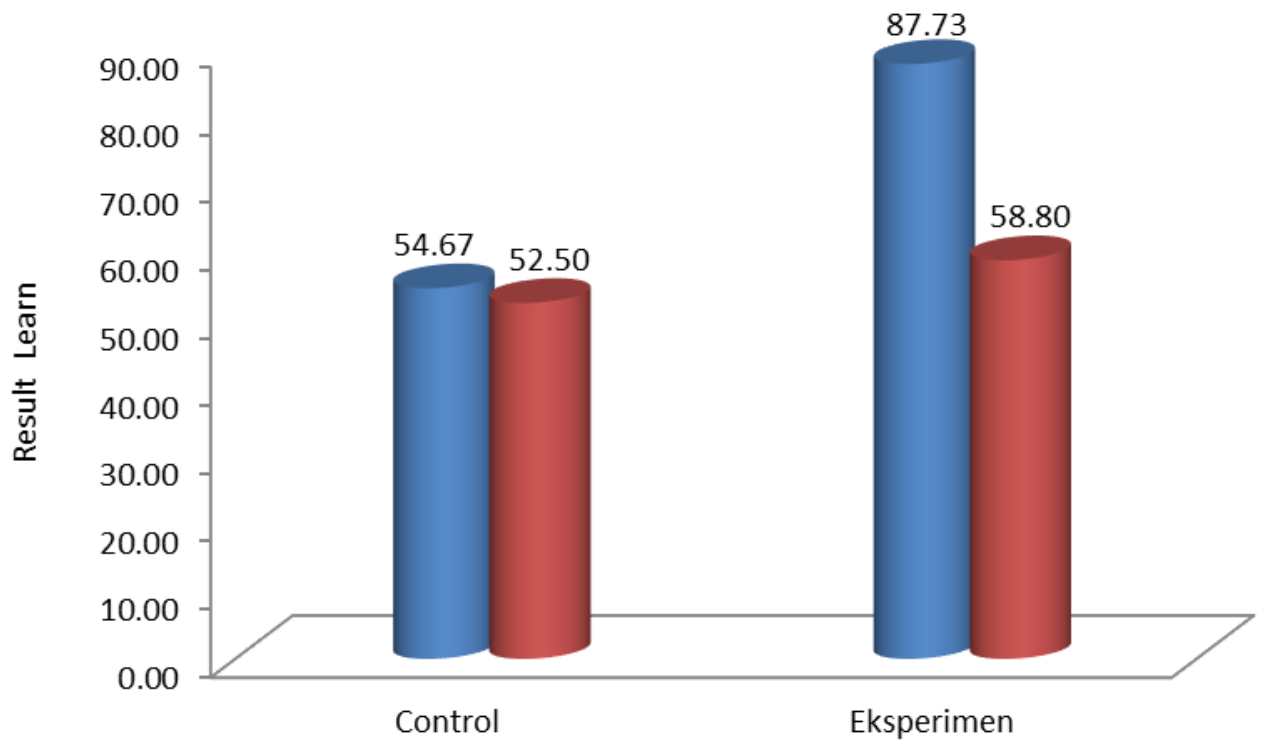

Figure 3.3 Frequency of Class Experimental Values and Control Classes

\section{Conclusion}

From the results of research and data analysis, it can be concluded that there is the influence of the use of Camtasia Studio 8 learning media on student learning outcomes in class VII Jambi Jambi Private Middle School, where student learning outcomes using Camtasia Studio 8 learning media are higher compared to using learning media usual grade VII school in Jambi Jambi Private Middle School The results obtained using Camtasia Studio 8 learning media amounted to 87.73, while the results obtained without using Camtasia Studio 8 learning media amounted to 58.80 .

\section{Bibliography}

Arikunto, S., 2013. Research Procedure: A Practice Approach. Jakarta: Rineka Cipta.

Arikunto, S., 2015. Basics of Educational Evaluation. Jakarta. Earth Literacy.

Aripin. 2009. Step by step make a video tutorial using Camtasia Studio. Bandung. Media Oasis.

Arsyad, Azhar. 2009. Learning Media. Jakarta: Rajawali Press

Computer Rides. 2011. It's easy to make a video tutorial with Camtasia Studio 8. Jakarta. Alex Media Komputindo.

Djamarah and Zain. 2006. Teaching and Learning Strategies. Jakarta. Rineka Cipta.

Ginting, Paham, 2006. Philosophy of Science and Research Methods, USU Press, Medan.

Kunandar. 2007. The Nature of Learning. Jakarta. Raja Grafindo Persada.

Saktiyono. 2007. Competence. Jakarta. Kencana Prenada Media Group.

Sanjaya. 2006. Learning Strategy. Jakarta. Kencana.

Sanjaya, W., 2011. Curriculum and Learning, Jakarta. Kencana Prenada.

Setyanto, Ardi. 2000. Guide to Success in Teaching and Learning Commonication. Jogjakarta. DIVA Press

Slameto. 2010. Learning and the factors that influence it. Jakarta. Rineka Cipta

Shah Muhibbin. 2009. Learning Psychology. Jakarta. Raja Grafindo Persada.

Sudijono. 2009. Introduction to Educational Evaluation. Jakarta. Raja Grafindo Persada.

Sudjana. 2001. Statistical Methods. Bandung. Tarsino.

Sugiyono. 2011. Statistics for Research. Bandung. Alfabeta.

Sukardi. 2003. Educational Research Methodology. Jakarta. Akasara Earth.

Sunarto. 2005. Understanding Learning Outcomes and Factors Affecting Learning Outcomes. Jakarta. Rineka

Suryabrata. 2010. Research Methodology. Jakarta. Raja Grafindo Persada.

TechSmit. 2005. Camtasia Show The World Studio. America.

Widodo. A., 2006. Revised Bloom's Taxonomy and Development of Question Items. Suspendik Bulletin. 